\begin{tabular}{lc|}
\hline Bentham open & The Open Biochemistry Journal \\
CrossMark & Content list available at: www.benthamopen.com/TOBIOCJ/ \\
DOI: $10.2174 / 1874091 \mathrm{X} 01711010066$ & \\
\hline
\end{tabular}

RESEARCH ARTICLE

\title{
Effects of Triton X-100 and PEG on the Catalytic Properties and Thermal Stability of Lipase from Candida Rugosa Free and Immobilized on Glyoxyl-Agarose
}

\author{
Rafael F. Perna ${ }^{1, *}$, Poliana C. Tiosso ${ }^{2}$, Letícia M. Sgobi ${ }^{3}$, Angélica M.S. Vieira ${ }^{3}$, Marcelo F. Vieira ${ }^{2}$, \\ Paulo W. Tardioli ${ }^{4}$, Cleide M.F. Soares ${ }^{5}$ and Gisella M Zanin ${ }^{2}$

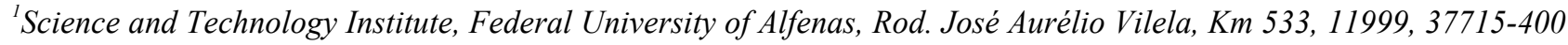 \\ Poços de Caldas, MG, Brazil \\ ${ }^{2}$ Department of Chemical Engineering, State University of Maringá, Av. Colombo, 5790, 87020-900 Maringá, PR.W, \\ Brazil \\ ${ }^{3}$ Department of Food Engineering, State University of Maringá, Av. Colombo, 5790, 87020-900 Maringá, PR.W, Brazil \\ ${ }^{4}$ Departmet of Chemical Engineering, Federal University of São Carlos, Rod. Washington Luis, Km 235, 13565-905, \\ São Carlos, SP, Brazil \\ ${ }^{5}$ Institute of Technology and Research, Tiradentes University, Av. Murilo Dantas, 300, 49032-490 Aracaju, SE, Brazil
}

Received: January 10, 2017

Revised: June 07, 2017

Accepted: June 23, 2017

\begin{abstract}
:
Background:

Candida rugosa Lipase (CRL) shows a very low alkaline stability that comprises its immobilization on glyoxyl-agarose, which requires $\mathrm{pH}$ above 10. In this way, an adaptation from the original method was used; an enzyme solution at $\mathrm{pH} 7$ was slowly added at a suspension of glyoxyl-agarose prepared in bicarbonate buffer, $\mathrm{pH}$ 10. This change of protocol was enough for allowing the preparation of derivatives actives of CRL on glyoxyl-agarose and verifying the effect of this modified procedure on the properties of the immobilized enzyme. The effect of the additives Triton-X-100 and polyethylene glycol (PEG) on the enzymatic activity recovery and immobilized enzyme stability was evaluated.
\end{abstract}

\section{Methods:}

The glyoxyl-agarose support was prepared by etherification of $6 \%$ agarose beads with glycidol and further oxidation with sodium periodate. CRL was immobilized covalently on glyoxyl-agarose support in the absence and presence of $1 \%$ (w/v) Triton-X-100 or 5 $\mathrm{g} \mathrm{L}^{-1}$ polyethylene glycol (PEG). The lipolysis activity of the free and immobilized enzyme was determined at $37^{\circ} \mathrm{C}$ and $\mathrm{pH} 7.0$, using p-nitrophenyl palmitate (p-NPP) as substrate. Profiles of temperature-activity $\left(37-65^{\circ} \mathrm{C}, \mathrm{pH} 7.0\right)$ and $\mathrm{pH}$-activity $\left(6.0-9.5,37^{\circ} \mathrm{C}\right)$ were evaluated as well as thermal $\left(45^{\circ} \mathrm{C}\right.$ and $\left.\mathrm{pH} 8.0\right)$ and operational $\left(15\right.$ min batches of p-NPP hydrolysis at $50^{\circ} \mathrm{C}$ and $\left.\mathrm{pH} 8.0\right)$ stabilities of free and immobilized CRL.

\section{Results:}

Using a single modification of the original protocol, the CRL poorly stable under alkaline conditions could be immobilized on glyoxyl-agarose in its active conformation (recovered activity varying from 10.3 to $30.4 \%$ ). Besides, the presence of a detergent (Triton-X-100) and an enzyme stabilizer (PEG) contributed to the preparation of more active and more stable biocatalysts, respectively. CRL immobilized on glyoxyl-agarose in the presence of PEG was around 5 times more stable than the free CRL and around 3 times more stable than the CRL immobilized on glyoxyl-agarose in absence of PEG. The higher stability of the

\footnotetext{
* Address correspondence to this author at the Science and Technology Institute, Federal University of Alfenas (ICT/UNIFAL-MG), Rod. José Aurélio Vilela, 11999 (BR 267, Km 533), 37715-400. City: Poços de Caldas. State: Minas Gerais, Brazil; Tel: +55 35 3697-4714; E-mails: rafael.perna@unifal-mg.edu.br, rafafpeng@gmail.com
} 
CRL-glyoxyl derivative prepared in the presence of PEG allowed its reuse in four successive 15 min-batches of p-nitrophenyl palmitate hydrolysis at $50^{\circ} \mathrm{C}$ and $\mathrm{pH} 8.0$.

\section{Conclusion:}

The technique of immobilizing enzymes covalently on glyoxyl-agarose showed promising results for Candida rugosa lipase (CRL). The derivatives prepared in the presence of the additives retained two to three times more activity than those prepared in the absence of additives. The enzyme immobilized in presence of PEG was about three times more stable than the enzyme immobilized in absence of this additive. Maximum catalytic activity of the immobilized CRL (in absence of additives) was observed in a temperature $10^{\circ} \mathrm{C}$ above that for the free enzyme and the $\mathrm{pH}$ of the maximum activity was maintained in the range 6.5-7.5 for free and immobilized CRL.

Keywords: Triton X-100, PEG, Stabilization, Candida rugosa Lipase, Immobilization, Glyoxyl-Agarose.

\section{INTRODUCTION}

Lipases (E.C. 3.1.1.3) are hydrolytic enzymes that catalyze the hydrolysis of triglycerides to produce mono and diacylglycerides, free fatty acids and glycerol. However, when water activity in the reaction medium is low, the majority of lipases can exert their reverse enzymatic activity, i.e., catalysis of esterification, transesterification (e.g., acidolysis, alcoholysis, and aminolysis), and interesterification reactions [1 - 8]. Because of this great catalytic versatility and their high stability in organic and aqueous medium, lipases currently have gained significant share of the world enzyme market.

In general, lipases act at a wide $\mathrm{pH}$ range, are stable at high temperatures and do not require cofactors. In addition, they exhibit high specificity and properties of regio-, chemo- and enantioselectivity [9, 10]. These enzymes are the most important among hydrolases due to their multiple applications in industrial processes. Lipases are used in the detergents, medicines, food, textiles, pulp and paper, cosmetics, biodiesel and biosensors industries, as well as applied in the treatment of effluents $[10,11]$.

Lipases show a typical mechanism of action called interfacial activation [12]. In aqueous media the active site is protected from the reaction medium by an oligopeptide chain known as "lid", which in the closed form turns the enzyme inactive [13]. The closed form of the lipase (closed lid) may exist in equilibrium with an open form, where the lid has been unlocked, allowing the access of the substrate to the active site [14]. When the enzyme is exposed to a hydrophobic interface (drops of oil, hydrophobic support surfaces, gas bubbles, hydrophobic proteins, lipopolysaccharides, etc), the lid is opened exposing hydrophobic residues located in the internal face of the lid and in the surroundings of the active site, shifting the equilibrium toward the open enzyme structure [12, 13, 15 - 18]. It have been reported that the presence of detergents in the lipase medium also favors the shifting of the equilibrium towards to the open lid form, allowing the fixation of the lipase on hydrophobic supports in a hyperactivated conformation [19 26]. Besides, lipases may exist in solution as biomolecular aggregates, in which the hydrophobic active centers of the monomers are in close contact, yielding more stable and less active structures. In presence of detergents, these aggregates are dissociated yielding less stable and more active monomers, which may be fixed on glyoxyl supports with the active center turned to the reaction medium [23].

In the last years, studies of lipase immobilization have increased considerably aiming their application in different fields, such as, hydrolysis of oils and fats, and esterification reactions for producing chemical compounds for food, cosmetic and nutraceutical industries [27 - 29]. Lipases from different microorganisms have been immobilized on various activated supports, such as, octyl-agarose, octadecyl-Sepabeads, DEAE-Sepharose, IDA-Cu ${ }^{+2}-\mathrm{Sepabeads,}$ MANAE-agarose, CNBr-Sepharose and glyoxyl-agarose [30 - 40].

Among the great number of activated supports available for immobilizing enzymes [41], active and stable derivatives of many enzymes have been produced using glyoxyl-agarose as support, such as Penicillin G acylase [42, 43], trypsin [44], chymotrypsin [45], thermophilic esterase [46], L-aminoacylase [47], chitosanase [48], carboxypeptiase A [49, 50], alcalase [51], cyclomaltodextrin glucanotransferase [52, 53] and lipase [23, 37, 54, 55].

Glyoxyl-agarose is composed of thick agarose fibers that hold a large number of very stable aldehyde groups linked to the support by very short spacer arms. Under alkaline conditions ( $\mathrm{pH}$ around 10.0), enzyme immobilization occurs through, at least, a two-point reaction between the protein surface region having higher densities of amino groups and the support aldehyde groups. A more intense multipoint attachment between the immobilized protein and the activated support can be reached, with minimal loss of catalytic activity, by a long-term incubation of the enzyme-support 
reaction medium under suitable conditions, such as temperature around $20-25^{\circ} \mathrm{C}$. The last step of the immobilization of an enzyme on glyoxyl-agarose is a very mild reduction using sodium borohydride. After that, the enzyme remains attached to the support by means of very stable secondary amino bonds (with physical properties very similar to the initial primary amines) and the non reacted aldehyde groups on the support are transformed into hydrophilic hydroxyl groups [21].

Palomo et al. [33] reported that lipase from Candida rugosa could not be immobilized on glyoxyl-agarose by the original protocol [45], which requires the suspension of the support in an enzyme solution at $\mathrm{pH} 10$. However, in this work, a simple modification of the original method allowed the immobilization of this lipase in this support: an enzyme solution at pH 7 was slowly added in a suspension of glyoxyl-agarose prepared in bicarbonate buffer $80 \mathrm{mM}, \mathrm{pH} 10$. Besides, CRL was also immobilized on glyoxyl-agarose in the presence of Triton-X-100 (a surfactant that may activate lipases and dissociate bimolecular aggregates) or polyethylene glycol (a stabilizer of enzymes) and their influence on the enzymatic activity recovery and thermal stability of the immobilized enzyme was evaluated.

\section{MATERIALS AND METHOD}

\subsection{Materials}

Lipase from Candida rugosa (type VII), glycidol (2,3-epoxy-1-propanol), p-nitrophenyl palmitate (p-NPP) and sodium borohydride were acquired from Sigma Chem. Co (St. Louis, MO, EUA). Sepharose CL-6B was purchased from Amersham Pharmacia Biotech AB (Uppsala, Sweden). Sodium metaperiodate, Triton X-100, gum arabic and polyethylene glycol (PEG- 1450) were purchased from Synth (Diadema, SP, Brazil). All other chemicals were of analytical grade.

\subsection{Preparation of CRL Glyoxyl-Agarose}

\subsubsection{Support Activation}

The glyoxyl-agarose support with high concentration of aldehyde groups per volume (around $75 \mu \mathrm{mol} \mathrm{mL}^{-1}$ ) was prepared by etherification of $6 \%$ agarose beads with glycidol and further oxidation with sodium periodate [42].

Under gentle stirring and in an ice bath, $105 \mathrm{~g}$ of agarose, previously washed with distilled water, were mixed with $30 \mathrm{~mL}$ of distilled water, and $50 \mathrm{~mL}$ of $1.7 \mathrm{~N} \mathrm{NaOH}$, containing $1.425 \mathrm{~g}$ sodium borohydride (previously cold prepared). After, $36 \mathrm{~mL}$ of glycidol were added dropwise to avoid raising the temperature above $25^{\circ} \mathrm{C}$, and the suspension formed was gently stirred for 12-15 h. The etherified support (glyceryl-agarose) was washed with distilled water, dried by vacuum suction in a sintered glass filter, and resuspended in $895 \mathrm{~mL}$ of water (volume ratio support:suspension of $1: 10)$. Sodium metaperiodate $(3.21 \mathrm{~g})$ was added and the suspension was gently stirred for $2 \mathrm{~h}$ at room temperature. Finally, the glyoxyl-agarose support was washed with water, filtered under vacuum and suck dried.

\subsubsection{Immobilization of Enzymes on Glyoxyl-Supports}

A mass of $10 \mathrm{~g}$ of glyoxyl-agarose were added to $90 \mathrm{~mL}$ of $80 \mathrm{mM}$ sodium bicarbonate buffer, $\mathrm{pH} 10$ and maintained under gentle agitation at $25^{\circ} \mathrm{C}$. Next, $10 \mathrm{~mL}$ of enzyme solution $(0.97$ to $4.87 \mathrm{mg}$ of protein $/ \mathrm{mL}) \mathrm{prepared} \mathrm{in}$ $50 \mathrm{mM}$ sodium phosphate buffer, $\mathrm{pH}$ 7.0, were slowly added. Then, this immobilization suspension was kept under gentle agitation at $25^{\circ} \mathrm{C}$ for two or four hours. The enzymatic activity of the initial solution and the final supernatant obtained after the immobilization period was measured to determine the amount of enzyme fixed in the support. After 4 $\mathrm{h}$ reaction time, no enzymatic activity was detected in the supernatant and the immobilized lipase derivative was reduced with sodium borohydride $\left(1 \mathrm{~g} \mathrm{~L}^{-1}, 25^{\circ} \mathrm{C}, 30 \mathrm{~min}\right)$, as described by Guisán and Blanco [44]. Then, the CRLderivative was washed with excess distilled water, filtered under vacuum, and suck dried.

CRL was also immobilized in the presence of $1 \%(\mathrm{w} / \mathrm{v})$ Triton-X-100 [56] or $5 \mathrm{gL}^{-1}$ polyethylene glycol (PEG).

All experiments were performed at least in triplicate and the standard deviations were less than $10 \%$.

\subsection{Activity Assay}

The lipolytic activity of the free and immobilized enzyme was determined at $37^{\circ} \mathrm{C}, \mathrm{pH} 7.0$, using p-nitrophenyl palmitate (p-NPP) as substrate [57]. An emulsion of $0.8 \mathrm{mM} \mathrm{p}-\mathrm{NPP}$ was prepared by mixing $1 \mathrm{~mL}$ of p-NPP solution (3 $\mathrm{gL}^{-1}$ in isopropanol) and $9 \mathrm{~mL}$ of $50 \mathrm{mM}$ phosphate buffer at $\mathrm{pH} 7.0$ containing Triton $\mathrm{X}-100$ and gum arabic 
(approximately 0.45 and $1.11 \mathrm{gL}^{-1}$, respectively).

For the free CRL, $0.3 \mathrm{~mL}$ of an enzyme solution (protein concentration equal to $9.74 \mu \mathrm{g} \mathrm{mL}^{-1}$ ) was mixed with 2.7 $\mathrm{mL}$ of substrate emulsion in a $1 \mathrm{~cm}$ optical length cuvette and the absorbance change at $37^{\circ} \mathrm{C}$ was monitored for $10 \mathrm{~min}$ at $410 \mathrm{~nm}$ in a UV-1203 spectrophotometer (Shimadzu Co., Japan), using pure substrate emulsion as reference. For the immobilized CRL, a mass of approximately $1 \mathrm{mg}$ of immobilized CRL was suspended in $30 \mathrm{~mL}$ of substrate emulsion in a batch reactor thermostatized at $37^{\circ} \mathrm{C}$ and samples were withdrawn at regular time intervals up to 10 min reaction for measuring the absorbance change at $410 \mathrm{~nm}$ in a UV-1203 spectrophotometer (Shimadzu Co., Japan), using pure substrate emulsion as reference.

The enzymatic activity per mass of enzyme $\left(\mathrm{U} \mathrm{g}^{-1}\right)$ was calculated with Equation 1:

$$
A=\frac{\Delta A B S \times V_{R}}{\varepsilon \times m_{E}} \times 10^{3}
$$

where $\triangle \mathrm{ABS}$ is the reaction medium absorbance change after $10 \mathrm{~min}$ reaction time (cuvette of $1 \mathrm{~cm}$ optical length); $V_{R}$ is the total reaction volume ( $3 \mathrm{~mL}$ for the free enzyme and $30 \mathrm{~mL}$ for the immobilized enzyme), $\varepsilon$ is molar extinction coefficient for the p-NPP $\left(\varepsilon=8.03 \times 10^{3} \mathrm{M}^{-1} \mathrm{~cm}^{-1}\right)$ and $\mathrm{m}_{\mathrm{E}}$ is the free or immobilized enzyme mass in $\mathrm{g}$. Factor $10^{3}$ was required for unit conversion (mol of p-nitrophenol to $\mu \mathrm{mol}$ of p-nitrophenol).

One Unit of enzymatic activity (U) was defined as the amount of enzyme that releases $1 \mu$ mol of p-nitrophenol per min under the experimental conditions describe above. Under these conditions the free CRL activity was $47.6 \pm 3.6 \mathrm{U}$ $\mathrm{mg}^{-1}$ of protein. The free enzyme protein content was $32.47 \mathrm{mg} \mathrm{g}^{-1}$ as determined by the Bradford's method [58].

\subsection{Temperature-activity and $\mathrm{pH}$-activity Profiles}

Enzymatic activities of free and immobilized CRL were measured at $37-65^{\circ} \mathrm{C}(\mathrm{pH} 7.0)$ and at $\mathrm{pH} 6.5-9.5\left(37^{\circ} \mathrm{C}\right)$, using p-NPP as substrate, using the activity method described in the Section 2.3. The molar extinction coefficients $\left(\mathrm{M}^{-1}\right.$ $\left.\mathrm{cm}^{-1}\right)$ at different $\mathrm{pH}$ were calculated for measurements of activity.

\subsection{Thermal and Operational Stability}

The thermal stability of the CRL-agarose biocatalysts was evaluated at $45^{\circ} \mathrm{C}$ and $\mathrm{pH} 8.0$. Biocatalyst suspensions were prepared in $50 \mathrm{mM}$ sodium phosphate buffer, containing Triton X-100 and gum arabic at the concentrations of 0.45 and $1.11 \mathrm{gL}^{-1}$, respectively. Residual activity was measured in 30 min intervals adding $0.8 \mathrm{mM} \mathrm{p}$-NPP solution prepared in isopropanol. After $15 \mathrm{~min}$ at $37^{\circ} \mathrm{C}$ the absorbance was measured at $410 \mathrm{~nm}$.

The parameters of thermal inactivation were estimated by fitting the model of Sadana and Henley [59] to the experimental data of residual activities vs. time (Eq. 2):

$$
\frac{A}{A_{0}}=\left(1-\alpha_{1}\right) \exp \left(-k_{1} t\right)+\alpha_{1}
$$

where $\mathrm{A} / \mathrm{A}$ is the dimensionless residual activity, $\alpha_{1}$ is the ratio of the specific activity of the final state to the initial state, and $\mathrm{k}_{1}$ is the first-order deactivation rate constant $\left(\operatorname{time}^{-1}\right)$.

The two-parameter model was fitted to the deactivation data using the Levenberg-Marquardt method of iterative convergence, at 0.95 confidence level. The catalyst half-life $\left(\mathrm{t}_{1 / 2}\right)$ was calculated using Eq. 3 :

$$
t_{\frac{1}{2}}=-\frac{1}{k_{1}} \ln \left(\frac{\frac{1}{2}-\alpha_{1}}{1-\alpha_{1}}\right)
$$

The operational stability of CRL-glyoxyl agarose derivatives prepared in the absence and presence of PEG was also evaluated at $50^{\circ} \mathrm{C}, \mathrm{pH} 8.0$ in reaction medium containing $1 \mathrm{~mL}$ of $\mathrm{p}-\mathrm{NPP}\left(3 \mathrm{gL}^{-1}\right.$ in isopropanol $)$ and $9 \mathrm{~mL}$ of $50 \mathrm{mM}$ phosphate buffer, $\mathrm{pH} 8.0$ containing Triton-X-100 $\left(0.45 \mathrm{gL}^{-1}\right)$ and gum Arabic $\left(1.11 \mathrm{gL}^{-1}\right)$. The residual activities of the biocatalysts were assessed in 15 min-intervals using the procedure described in section 2.3. 


\section{RESULTS AND DISCUSSION}

\subsection{Immobilization of CRL on Glyoxyl-Agarose}

All CRL-derivatives prepared according to Section 2.2 .2 achieved 100\% immobilization yield, i.e., all protein offered to the support ( 1 or $5 \mathrm{mg} \mathrm{g}^{-1}$ ) was immobilized.

Table 1 shows great losses of enzyme activity (65-87\%) for CRL immobilized on glyoxyl-agarose in absence or presence of Triton-X-100 or PEG. These losses are probably associated to the low enzyme stability at alkaline pH [33]. In fact, the immobilization of CRL according to the original protocol [42], in absence or presence of additives, resulted in biocatalysts completely inactivated. On the other hand, the slowly enzyme addition was sufficient for allowing the preparation of active CRL derivatives.

Table 1. CRL immobilization on glyoxyl-agarose $\left(25^{\circ} \mathrm{C}, \mathrm{pH} 10\right)$.

\begin{tabular}{|c|c|c|c|}
\hline Additive & $\begin{array}{l}\text { Enzyme Activity Offered per Mass of Support } \\
\qquad\left(\mathrm{U} \mathrm{g} \mathrm{g}^{-1}\right)\end{array}$ & $\begin{array}{c}\text { IE }^{\mathrm{b}} \text { Activity per Mass of Support } \\
\left(\mathrm{U} \mathrm{g}^{-1}\right)\end{array}$ & \begin{tabular}{|c|} 
Activity Recovery $^{\mathrm{d}}$ \\
(\%)
\end{tabular} \\
\hline Absence $^{a}$ & 46.2 & 5.8 & 12.6 \\
\hline $\begin{array}{l}\text { Triton-X-100 } \\
(1 \%, \mathrm{w} / \mathrm{v})^{\mathrm{c}}\end{array}$ & 231.8 & 82.1 & 35.4 \\
\hline $\operatorname{PEG}\left(\mathrm{g} \mathrm{L}^{-1}\right)^{\mathrm{c}}$ & 231.8 & 58.2 & 25.1 \\
\hline
\end{tabular}

${ }^{a}$ Enzyme load offered as protein mass per support mass, about $1 \mathrm{mg} \mathrm{g}^{-1}$ and reaction time of $2 \mathrm{~h}$. ${ }^{\mathrm{b}}$ IE - Immobilized enzyme (derivative CRLagarose). ${ }^{\mathrm{c}}$ Enzyme load offered as protein per support mass, about $5 \mathrm{mg} \mathrm{g}^{-1}$ and reaction time of $4 \mathrm{~h}$. ${ }^{\mathrm{d}}$ Activity recovery was defined as the ratio of the immobilized enzyme activity and the enzyme activity offered for immobilization per gram of support. Results are expressed as average of triplicate assays (standard deviations less than 10\%). Activities were measured at $37^{\circ} \mathrm{C}$ and $\mathrm{pH} 7.0$ using olive oil as substrate (Section $2.3-$ Activity assay).

The use of Triton-X-100 (1\%,w/v) yielded recovered activity higher than that obtained with PEG $\left(5 \mathrm{gL}^{-1}\right)$, which may be associated with the dissociation of bimolecular aggregates (more stable and less active), allowing the immobilization of CRL molecules on glyoxyl-agarose as monomers (less stable and more active) [23]. It have been reported that the addition of a detergent under the critical micellar concentration may increase the lipase activity by shifting the conformational equilibrium of lipases toward the open form. However, detergents may also have negative effects on enzyme activity above a certain concentration [60].

The stabilizing effect of additives on the activity of an enzyme, such as sugars and polyols (e.g., PEG), is based on the reduction of the dielectric constant of the solution compared to the pure water. Consequently, dielectric interactions, as well as hydrophobic ones, between enzyme functional groups should be stronger, making the enzyme molecule more rigid and thus more thermally stable [61]. This effect may have contributed to preserve the CRL activity in alkaline $\mathrm{pH}$, but without allowing the immobilization of the enzyme in the monomeric and more active form because of the greater rigidity of the molecule in the presence of PEG impairing the bimolecular aggregate dissociation. This may explain the lower activity recovered when PEG was used as additive instead Triton-X-100 for CRL immobilization.

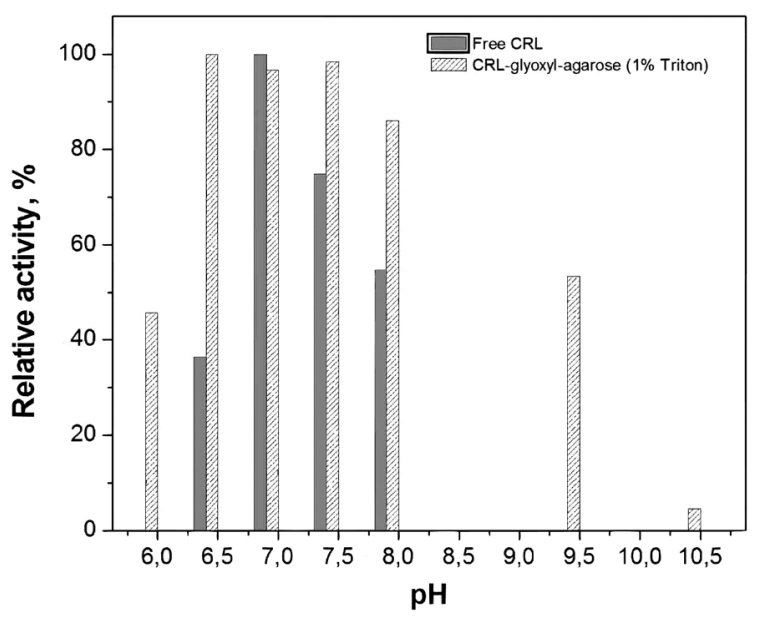

Fig. (1). Activity-pH profiles of CRL free and immobilized on glyoxyl-agarose in absence and presence of Triton-X-100 and PEG. Activities were measured at $37^{\circ} \mathrm{C}$ and the maximum activity was taken as $100 \%$. 


\subsection{Profiles of Activity vs $\mathrm{pH}$ and Temperature}

The activity-pH profile for free and immobilized CRL was evaluated in the range 6.0-10.5. Fig. (1) shows that the $\mathrm{pH}$ of maximum activity was 7.0 for free CRL and 6.5-7.5 for immobilized CRL in the presence of Triton-X-100 (1\%, $\mathrm{w} / \mathrm{v})$, which is consistent with the fact that glyoxyl-agarose is a non-charged support, therefore not changing the microenvironment closed to the immobilized lipase [62]. Similar behavior was also reported by Pereira et al. [63] for CRL immobilized on chitosan and by Soares et al. [64] for CRL encapsulated into hydrophobic sol-gel matrix.

The catalytic activity for free and immobilized CRL was measured at $\mathrm{pH} 7.0$ in the temperature range of $37-60^{\circ} \mathrm{C}$. Fig. (2) shows that for immobilized lipases the temperature of maximum catalytic activity occurs between 45 and $50^{\circ} \mathrm{C}$ (except for CRL immobilized in presence of PEG), while for free CRL this maximum is found approximately at $40^{\circ} \mathrm{C}$. Similar behavior has been previously reported $[63-66]$. The $5-10^{\circ} \mathrm{C}$ raise in the maximum activity temperature for immobilized CRL demonstrates its greater stability as consequence of the 3D-structure rigidification promoted probably by the formation of multiple covalent links enzyme-support.

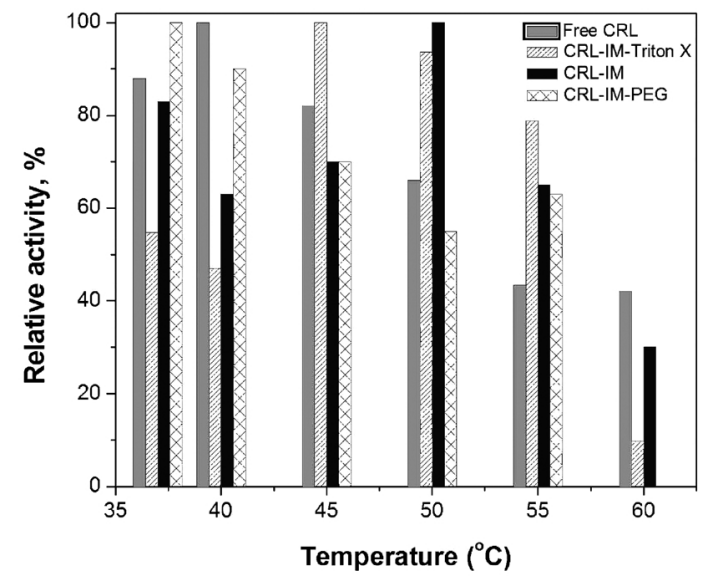

Fig. (2). Activity-temperature profiles of CRL free and immobilized on glyoxyl-agarose in absence and presence of Triton-X-100 and PEG. Activities were measured at $\mathrm{pH} 7.0$ and the maximum activity was taken as $100 \%$.

\subsection{Thermal and Operational Stability}

Fig. (3) shows the inactivation profiles of free and immobilized CRL at $45^{\circ} \mathrm{C}$ and $\mathrm{pH} 8.0$ during a time period of 120 min. CRL free and immobilized on glyoxyl-agarose (presence of Triton-X-100) showed similar behavior of inactivation, rapidly dropping its initial activity to around $30 \%$ after 30 min incubation. On the other hand, in same time interval, CRL immobilized in the presence of PEG retained around $95 \%$ of its initial activity.

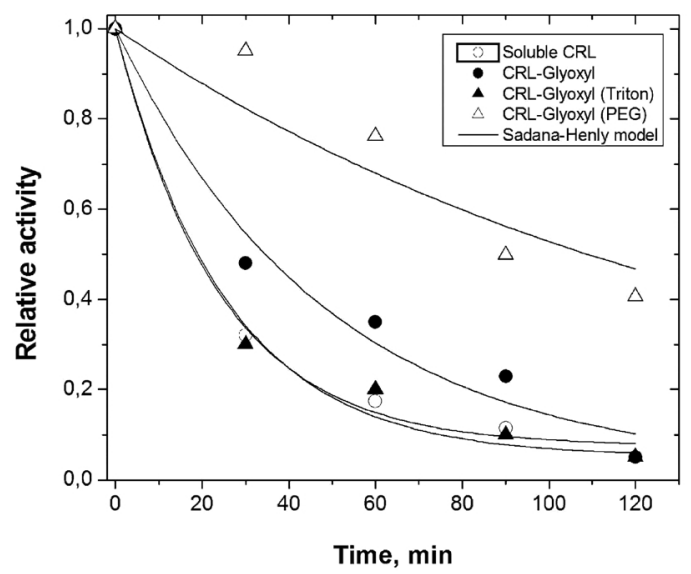

Fig. (3). Thermal stability at $45^{\circ} \mathrm{C}$ and $\mathrm{pH} 8.0$ for CRL free and immobilized on glyoxyl-agarose (absence and presence of Triton$\mathrm{X}-100$ and PEG). Half-lives estimated by Sadana-Henley model [57]: free CRL $\left(\mathrm{t}_{1 / 2}=18.5 \mathrm{~min}\right)$; CRL-glyoxyl $\left(\mathrm{t}_{1 / 2}=34.5 \mathrm{~min}\right)$; CRL-glyoxyl, presence of Triton-X-100 ( $\left.\mathrm{t}_{1 / 2}=19.0 \mathrm{~min}\right)$; CRL-glyoxyl, presence of PEG $\left(\mathrm{t}_{1 / 2}=109 \mathrm{~min}\right)$. 
The half-lives of CRL immobilized on glyoxyl-agarose in the absence and presence of PEG were estimated as 34.5 and $109 \mathrm{~min}$, respectively, representing a stabilization factor around 3 times. Compared to the free CRL (half-life around $18.5 \mathrm{~min}$ ), the CRL immobilized on glyoxyl-agarose in presence of PEG showed to be around 6 times more stable.

Probably, CRL was immobilized on glyoxyl-agarose (absence and presence of PEG) as bimolecular aggregates (more stable and less active) and CRL was immobilized on glyoxyl-agarose (presence of Triton-X-100) as monomers (more active and less stable).

The operational stability is a parameter of fundamental importance when it is desired to use the immobilized enzyme industrially [67]. Therefore, the stability of the immobilized biocatalysts prepared in the absence and presence of PEG (the most thermally stable biocatalysts) were evaluated in the reaction medium of p-NPP hydrolysis at $50^{\circ} \mathrm{C}$ and pH 8.0. Fig. (4) shows that CRL immobilized on glyoxyl-agarose in the presence of PEG was around 3 times more stable than the one immobilized in absence of PEG. This result shows the stabilizing effect of PEG, allowing the immobilization of CRL on glyoxyl-agarose in a rigid and stable conformation.

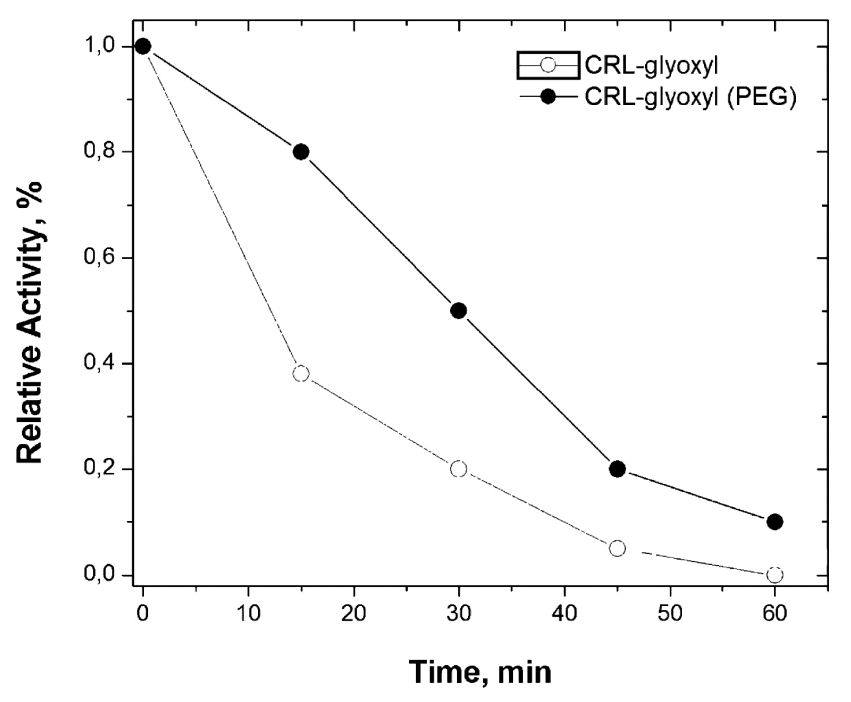

Fig. (4). Thermal stability at $50^{\circ} \mathrm{C}$ and $\mathrm{pH} 8.0$ for CRL immobilized on glyoxyl-agarose (absence and presence of PEG) in the reaction medium of p-NPP hydrolysis. Half-lives estimated by Sadana-Henley model [59]: absence of PEG $\left(\mathrm{t}_{1 / 2}=11 \mathrm{~min}\right)$; presence of PEG $\left(\mathrm{t}_{1 / 2}=30 \mathrm{~min}\right)$.

\section{CONCLUSION}

The technique of immobilizing enzymes covalently on glyoxyl-agarose showed promising results for Candida rugosa lipase (CRL). Using a single modification of the original protocol, i.e., adding slowly the enzyme solution prepared at $\mathrm{pH} 7.0$ in the support suspension prepared at $\mathrm{pH} 10.0$ instead of preparing the enzyme solution directly at $\mathrm{pH}$ 10.0, the CRL poorly stable under alkaline conditions could be immobilized on glyoxyl-agarose in its active conformation (recovered activity varying from 10.3 to $30.4 \%$ ). Besides, the presence of a detergent (Triton-X-100) and an enzyme stabilizer (PEG) contributed to the preparation of more active and more stable biocatalysts, respectively. CRL immobilized on glyoxyl-agarose in the presence of PEG was around 5 times more stable than the free CRL and around 3 times more stable than the CRL immobilized on glyoxyl-agarose in absence of PEG. The higher stability of the CRL-glyoxyl derivative prepared in the presence of PEG allowed its reuse in four successive 15 min-batches of pnitrophenyl palmitate hydrolysis at $50^{\circ} \mathrm{C}$ and $\mathrm{pH} 8.0$.

\section{ETHICS APPROVAL AND CONSENT TO PARTICIPATE}

Not applicable.

\section{HUMAN AND ANIMAL RIGHTS}

No Animals/Humans were used for studies that are base of this research. 


\section{CONSENT FOR PUBLICATION}

Not applicable.

\section{CONFLICT OF INTEREST}

The authors declare no conflict of interest, financial or otherwise.

\section{ACKNOWLEDGEMENTS}

The authors thank National Counsel of Technological and Scientific Development (CNPq), Coordination for the Improvement of Higher Education Personnel (CAPES) and Araucária Foundation for the financial support.

\section{REFERENCES}

[1] Castro, H.F.; Anderson, W.A. Fine chemicals by biotransformation using lipases. Quim. Nova, 1995, 18, $544-554$.

[2] Costa, V.E.; Amorim, H.L. The use of lipases as agents of kinetic resolution of enantiomers in organic synthesis: general aspects of solvent's influence. Quim. Nova, 1999, 22, 863-873.

[http://dx.doi.org/10.1590/S0100-40421999000600014]

[3] Bora, L.; Gohain, D.; Das, R. Recent advances in production and biotechnological applications of thermostable and alkaline bacterial lipases. J. Chem. Technol. Biotechnol., 2013, 88, 1959-1970.

[4] Gupta, R.; Kumari, A.; Syal, P.; Singh, Y. Molecular and functional diversity of yeast and fungal lipases: their role in biotechnology and cellular physiology. Prog. Lipid Res., 2015, 57, 40-54. [http://dx.doi.org/10.1016/j.plipres.2014.12.001] [PMID: 25573113]

[5] Chen, H.; Wu, J.; Yang, L.; Xu, G. Characterization and structure basis of Pseudomonas alcaligenes lipase's enantiopreference towards D,Lmenthyl propionate. J. Mol. Catal., B Enzym., 2014, 102, 81-87. [http://dx.doi.org/10.1016/j.molcatb.2014.01.020]

[6] Villalba, M.; Verdasco-Martín, C.M.; Dos Santos, J.C.; Fernandez-Lafuente, R.; Otero, C. Operational stabilities of different chemical derivatives of Novozym 435 in an alcoholysis reaction. Enzyme Microb. Technol., 2016, 90, 35-44. [http://dx.doi.org/10.1016/j.enzmictec.2016.04.007] [PMID: 27241290]

[7] Mouad, A.M.; Taupin, D.; Lehr, L.; Yvergnaux, F.; Porto, A.L. Aminolysis of linoleic and salicylic acid derivatives with Candida antarctica lipase B: A solvent-free process to obtain amphiphilic amides for cosmetic application. J. Mol. Catal., B Enzym., 2016, 126, 64-68. [http://dx.doi.org/10.1016/j.molcatb.2016.01.002]

[8] Verdasco-Martín, C.; Villalba, M.; Dos Santos, J.C.; Tobajas, M.; Fernandez-Lafuente, R.; Otero, C. Effect of chemical modification of Novozym 435 on its performance in the alcoholysis of camelina oil. Biochem. Eng. J., 2016, 111, 75-86. [http://dx.doi.org/10.1016/j.bej.2016.03.004]

[9] Villeneuve, P.; Muderhwa, J.M.; Graille, J.; Haas, M.J. Customizing lipases for biocatalysis: a survey of chemical, physical and molecular biological approaches. J. Mol. Catal., B Enzym., 2000, 9, 113-148. [http://dx.doi.org/10.1016/S1381-1177(99)00107-1]

[10] Hasan, F.; Shah, A.A.; Hameed, A. Industrial applications of microbial lipases. Enzyme Microb. Technol., 2006, 39, $235-251$. [http://dx.doi.org/10.1016/j.enzmictec.2005.10.016]

[11] Houde, A.; Kademi, A.; Leblanc, D. Lipases and their industrial applications: an overview. Appl. Biochem. Biotechnol., 2004, 118(1-3), $155-170$.

[http://dx.doi.org/10.1385/ABAB:118:1-3:155] [PMID: 15304746]

[12] Verger, R. Interfacial activation' of lipases: facts and artifacts. Trends Biotechnol., 1997, 15, 32-38. [http://dx.doi.org/10.1016/S0167-7799(96)10064-0]

[13] Brzozowski, A.M.; Derewenda, U.; Derewenda, Z.S.; Dodson, G.G.; Lawson, D.M.; Turkenburg, J.P.; Björkling, F.; Huge-Jensen, B.; Patkar, S.A.; Thim, L. A model for interfacial activation in lipases from the structure of a fungal lipase-inhibitor complex. Nature, 1991, 351(6326), 491-494.

[http://dx.doi.org/10.1038/351491a0] [PMID: 2046751]

[14] Kim, K.K.; Song, H.K.; Shin, D.H.; Hwang, K.Y.; Suh, S.W. The crystal structure of a triacylglycerol lipase from Pseudomonas cepacia reveals a highly open conformation in the absence of a bound inhibitor. Structure, 1997, 5(2), 173-185. [http://dx.doi.org/10.1016/S0969-2126(97)00177-9] [PMID: 9032073]

[15] Otero, C.; Fernández-Péreza, M.; Hermosob, J.A.; Ripollb, M.M. Activation in the family of Candida rugosa isolipases by polyethylene glycol. J. Mol. Catal., B Enzym., 2005, 32, 225-229. [http://dx.doi.org/10.1016/j.molcatb.2004.12.008]

[16] Nagarajan, S. New tools for exploring “old friends-microbial lipases”. Appl. Biochem. Biotechnol., 2012, 168(5), 1163-1196. [http://dx.doi.org/10.1007/s12010-012-9849-7] [PMID: 22956276]

[17] Ramos, E.Z.; Miotti Júnior, R.H.; Castro, P.F.; Tardioli, P.W.; Mendes, A.A.; Fernandéz-Lafuente, R.; Hirata, D.B. Production and 
immobilization of Geotrichum candidum lipase via physical adsorption on eco-friendly support: characterization of the catalytic properties in hydrolysis and esterification reactions. J. Mol. Catal., B Enzym., 2015, 118, 43-51.

[http://dx.doi.org/10.1016/j.molcatb.2015.05.009]

[18] Manoel, E.A.; Dos Santos, J.C.; Freire, D.M.; Rueda, N.; Fernandez-Lafuente, R. Immobilization of lipases on hydrophobic supports involves the open form of the enzyme. Enzyme Microb. Technol., 2015, 71, 53-57. [http://dx.doi.org/10.1016/j.enzmictec.2015.02.001] [PMID: 25765310]

[19] Fernandez-Lorente, G.; Palomo, J.M.; Cabrera, Z.; Fernandez-Lafuente, R.; Guisán, J.M. Improved catalytic properties of immobilized lipases by the presence of very low concentrations of detergents in the reaction medium. Biotechnol. Bioeng., 2007, 97(2), 242-250. [http://dx.doi.org/10.1002/bit.21230] [PMID: 17054124]

[20] Helistö, P.; Korpela, T. Effects of detergents on activity of microbial lipases as measured by the nitrophenyl alkanoate esters method. Enzyme Microb. Technol., 1998, 23, 113-117. [http://dx.doi.org/10.1016/S0141-0229(98)00024-6]

[21] Mateo, C.; Palomo, J.M.; Fuentes, M.; Betancor, L.; Grazu, V.; López-Gallego, F.; Pessela, B.C.; Hidalgo, A.; Fernández-Lorente, G.; Fernández-Lafuente, R.; Guisán, J.M. Glyoxyl agarose: A fully inert and hydrophilic support for immobilization and high stabilization of proteins. Enzyme Microb. Technol., 2006, 39, 274-280. [http://dx.doi.org/10.1016/j.enzmictec.2005.10.014]

[22] Mogensen, J.E.; Sehgal, P.; Otzen, D.E. Activation, inhibition, and destabilization of Thermomyces lanuginosus lipase by detergents. Biochemistry, 2005, 44(5), 1719-1730. [http://dx.doi.org/10.1021/bi0479757] [PMID: 15683256]

[23] Lima, L.N.; Aragon, C.C.; Mateo, C.; Polomo, J.M.; Giordano, R.L.; Tardioli, P.W.; Guisán, J.M.; Fernandez-Lorente, G. Immobilization and stabilization of a bimolecular aggregate of the lipase from Pseudomonas fluorescens by multipoint covalent attachment. Process Biochem., 2013, 48, 118-123.

[http://dx.doi.org/10.1016/j.procbio.2012.11.008]

[24] Garcia-Galan, C.; Dos Santos, J.C.; Barbosa, O.; Torres, R.; Pereira, E.B.; Corberan, V.C.; Gonçalves, L.R.; Fernandez-Lafuente, R. Tuning of Lecitase features via solid-phase chemical modification: Effect of the immobilization protocol. Process Biochem., 2014, 49, 604-616. [http://dx.doi.org/10.1016/j.procbio.2014.01.028]

[25] Dos Santos, J.C.; Garcia-Galan, C.; Rodrigues, R.C.; De Sant' Ana, H.B.; Gonçalves, L.R.; Fernandez-Lafuente, R. Improving the catalytic properties of immobilized Lecitase via physical coating with ionic polymers. Enzyme Microb. Technol., 2014, 60, 1-8. [http://dx.doi.org/10.1016/j.enzmictec.2014.03.001] [PMID: 24835093]

[26] Dos Santos, J.C.; Garcia-Galan, C.; Rodrigues, R.C.; De Sant'Ana, H.B.; Gonçalves, L.R.; Fernandez-Lafuente, R. Stabilizing hyperactivated lecitase structures through physical treatment with ionic polymers. Process Biochem., 2014, 49, 1511-1515. [http://dx.doi.org/10.1016/j.procbio.2014.05.009]

[27] Lage, F.A.; Bassi, J.J.; Corradini, M.C.; Todero, L.M.; Luiz, J.H.; Mendes, A.A. Preparation of a biocatalyst via physical adsorption of lipase from Thermomyces lanuginosus on hydrophobic support to catalyze biolubricant synthesis by esterification reaction in a solvent-free system. Enzyme Microb. Technol., 2016, 84, 56-67. [http://dx.doi.org/10.1016/j.enzmictec.2015.12.007] [PMID: 26827775]

[28] Souza, T.C.; Fonseca, T.S.; Costa, J.A.; Rocha, M.V.; Mattos, M.C.; Fernandez-Lafuente, R.; Gonçalves, L.R.; Dos Santos, J.C. Cashew apple bagasse as a support for the immobilization of lipase B from Candida antarctica: Application to the chemoenzymatic production of (R)Indanol. J. Mol. Catal., B Enzym., 2016, 130, 58-69. [http://dx.doi.org/10.1016/j.molcatb.2016.05.007]

[29] Costa, V.M.; Souza, M.C.; Fechine, P.B.; Macedo, A.C.; Gonçalves, L.R. Nanobiocatalytic systems based on lipase-Fe ${ }_{3} \mathrm{O}_{4}$ and conventional systems for isoniazid synthesis: A comparative study. Braz. J. Chem. Eng., 2016, 33, 661-673. [http://dx.doi.org/10.1590/0104-6632.20160333s20150137]

[30] Cunha, A.G.; Fernández-Lorente, G.; Bevilaqua, J.V.; Destain, J.; Paiva, L.M.; Freire, D.M.; Fernández-Lafuente, R.; Guisán, J.M. Immobilization of Yarrowia lipolytica lipase-a comparison of stability of physical adsorption and covalent attachment techniques. Appl. Biochem. Biotechnol., 2008, 146(1-3), 49-56.

[http://dx.doi.org/10.1007/s12010-007-8073-3] [PMID: 18421586]

[31] Fernández-Lorente, G.; Ortiz, C.; Segura, R.L.; Fernández-Lafuente, R.; Guisán, J.M.; Palomo, J.M. Purification of different lipases from Aspergillus niger by using a highly selective adsorption on hydrophobic supports. Biotechnol. Bioeng., 2005, 92(6), $773-779$. [http://dx.doi.org/10.1002/bit.20656] [PMID: 16155948]

[32] Nieto, I.; Rocchietti, S.; Ubiali, D.; Speranza, G.; Morelli, C.F.; Fuentes, i.e.; Alcântara, A.R.; Terreni, M. Immobilization of different protein fractions from Rhizomucor miehei lipase crude extract-Enzymatic resolution of (R,S)-2-tetralol. Enzyme Microb. Technol., 2005, 37, 514-520. [http://dx.doi.org/10.1016/j.enzmictec.2005.03.027]

[33] Palomo, J.M.; Munoz, G.; Fernandez-Lorente, G.; Mateo, C.; Fernandez-Lafuente, R.; Guisán, J.M. Interfacial adsorption of lipases on very hydrophobic support (octadecyl-Sepabeads): immobilization, hyperactivation and stabilization of the open form of lipases. J. Mol. Catal., $B$ Enzym., 2002, 19-20, 279-286. [http://dx.doi.org/10.1016/S1381-1177(02)00178-9]

[34] Palomo, J.M.; Mateo, C.; Fernández-Lorente, G.; Solares, L.F.; Diaz, M.; Sanchez, V.M.; Bayod, M.; Gotor, V.; Guisán, J.M.; FernandezLafuente, R. Resolution of ( \pm )-5-substituted-6-(5-chloropyridin-2-yl)-7-oxo 5, dihydropyrrolo[3,4b]pyrazine derivatives-precursors of (S)-(+)- 
Zopiclone, catalyzed by immobilized Candida antarctica B lipase in aqueous media. Tetrahedron Asymmetry, 2003, 14, 429-438. [http://dx.doi.org/10.1016/S0957-4166(02)00867-4]

[35] Palomo, J.M.; Segura, R.L.; Fernández-Lorente, G.; Pernas, M.; Rua, M.L.; Guisán, J.M.; Fernández-Lafuente, R. Purification, immobilization, and stabilization of a lipase from Bacillus thermocatenulatus by interfacial adsorption on hydrophobic supports. Biotechnol. Prog., 2004, 20(2), 630-635.

[http://dx.doi.org/10.1021/bp0342957] [PMID: 15059012]

[36] Wilson, L.; Palomo, J.M.; Fernandez-Lorente, G.; Illanes, A.; Guisán, J.M.; Fernandez-Lafuente, R. Improvement of the functional properties of a thermostable lipase from Alcaligenes sp. via strong adsorption on hydrophobic supports. Enzyme Microb. Technol., 2006, 38, 975-980. [http://dx.doi.org/10.1016/j.enzmictec.2005.08.032]

[37] Rodrigues, D.S.; Mendes, A.A.; Adriano, W.S.; Gonçalves, L.R.; Giordano, R.L. Multipoint covalent immobilization of microbial lipase on chitosan and agarose activated by different methods. J. Mol. Catal., B Enzym., 2008, 51, 100-109. [http://dx.doi.org/10.1016/j.molcatb.2007.11.016]

[38] Ali, Z.; Tian, L.; Zhao, P.; Zhang, B.; Ali, N.; Khan, M.; Zhang, Q. Immobilization of lipase on mesoporous silica nanoparticles with hierarchical fibrous pore. J. Mol. Catal., B Enzym., 2016, 134, 129-135. [http://dx.doi.org/10.1016/j.molcatb.2016.10.011]

[39] Rueda, N.; Dos Santos, J.C.; Ortiz, C.; Barbosa, O.; Fernandez-Lafuente, R.; Torres, R. Chemical amination of lipases improves their immobilization on octyl-glyoxyl agarose beads. Catal. Today, 2016, 259, 107-118. [http://dx.doi.org/10.1016/j.cattod.2015.05.027]

[40] Cai, C.; Gao, Y.; Liu, Y.; Zhong, N.; Liu, N. Immobilization of Candida antarctica lipase B onto SBA-15 and their application in glycerolysis for diacylglycerols synthesis. Food Chem., 2016, 212, 205-212. [http://dx.doi.org/10.1016/j.foodchem.2016.05.167] [PMID: 27374525]

[41] Dos Santos, J.C.; Barbosa, O.; Ortiz, C.; Berenguer-Murcia, A.; Rodrigues, R.C.; Fernandez-Lafuente, R. Importance of the support properties for immobilization or purification of enzymes. Chem CatChem, 2015, 7, 2413-2432. [http://dx.doi.org/10.1002/cctc.201500310]

[42] Guisán, J.M. Aldehyde-agarose gels as activated supports for immobilization-stabilization of enzymes. Enzyme Microb. Technol., 1988, 10, 375-382. [http://dx.doi.org/10.1016/0141-0229(88)90018-X]

[43] Pereira, G.H.; Guisán, J.M.; Giordano, R.L. Multi-point immobilization of penicillin G acylase on silica-glyoxyl: Influence of the degree of activation. Braz. J. Chem. Eng., 1997, 14, 327-331. [http://dx.doi.org/10.1590/S0104-66321997000400005]

[44] Guisán, J.M.; Blanco, R.M. Stabilization of trypsin by multiple-point attachment to aldehyde-agarose gels. Ann. N. Y. Acad. Sci., 1987, 501, 67-72. [http://dx.doi.org/10.1111/j.1749-6632.1987.tb45686.x] [PMID: 3475029]

[45] Guisán, J.M.; Bastida, A.; Cuesta, C.; Fernandez-Lufuente, R.; Rosell, C.M. Immobilization-stabilization of $\alpha$-chymotrypsin by covalent attachment to aldehyde-agarose gels. Biotechnol. Bioeng., 1991, 38(10), 1144-1152. [http://dx.doi.org/10.1002/bit.260381005] [PMID: 18600709]

[46] Fernandez-Lafuente, R.; Cowan, D.A.; Wood, A.N. Hyperstabilization of a thermophilic esterase by multipoint covalent attachment. Enzyme Microb. Technol., 1995, 17, 366-372.

[http://dx.doi.org/10.1016/0141-0229(94)00089-1]

[47] Toogood, H.S.; Taylor, J.N.; Brown, R.C.; Taylor, S.J.; Maccague, R.; Littlechild, A. Immobilization of the thermostable 1-aminoacylase from thermococcus litoralis to generate a reusable industrial biocatalyst. Biocatal. Biotransform., 2002, 20, 241-249. [http://dx.doi.org/10.1080/10242420290029472]

[48] Ichikawa, S.; Tanako, K.; Kuroiwa, Y.; Hiruta, T.; Sato, S.; Mukataka, S. Imobilization of chitosanase by multipoint covalent attachment to agar gel support. J. Biosci. Bioeng., 2002, 2, 201-206. [http://dx.doi.org/10.1016/S1389-1723(02)80014-7] [PMID: 16233187]

[49] Pedroche, J.; Mar Yust, M.; Giróncalle, J.; Vioque, J.; Alaiz, M.; Mateo, C.; Guisán, J.M.; Lillán, F. Stabilization-immobilization of carboxypeptidase A to aldehyde-agarose gels. A pratical example in the hydrolysis of casein. Enzyme Microb. Technol., 2002, 31, 711-718. [http://dx.doi.org/10.1016/S0141-0229(02)00170-9]

[50] Tardioli, P.W.; Fernández-Lafuente, R.; Guisán, J.M.; Giordano, R.L. Design of new immobilized-stabilized carboxypeptidase a derivative for production of aromatic free hydrolysates of proteins. Biotechnol. Prog., 2003, 19(2), 565-574. [http://dx.doi.org/10.1021/bp0256364] [PMID: 12675602]

[51] Tardioli, P.W.; Pedroche, J.; Giordano, R.L.; Fernández-Lafuente, R.; Guisán, J.M. Hydrolysis of proteins by immobilized-stabilized alcalaseglyoxyl agarose. Biotechnol. Prog., 2003, 19(2), 352-360. [http://dx.doi.org/10.1021/bp025588n] [PMID: 12675571]

[52] Tardioli, P.W.; Zanin, G.M.; Moraes, F.F. Characterization of Thermoanaerobacter cyclomaltodextrin glucanotransferase immobilized on glyoxyl-agarose. Enzyme Microb. Technol., 2006, 39, 1270-1278.

[http://dx.doi.org/10.1016/j.enzmictec.2006.03.011] 
[53] Ferrarotti, S.A.; Bolivar, J.M.; Mateo, C.; Wilson, L.; Guisan, J.M.; Fernandez-Lafuente, R. Immobilization and stabilization of a cyclodextrin glycosyltransferase by covalent attachment on highly activated glyoxyl-agarose supports. Biotechnol. Prog., 2006, 22(4), 1140-1145. [http://dx.doi.org/10.1021/bp0600740] [PMID: 16889391]

[54] Osuna, Y.; Sandoval, J.; Saade, H.; López, R.G.; Martinez, J.L.; Colunga, E.M.; de la Cruz, G.; Segura, E.P.; Arévalo, F.J.; Zon, M.A.; Fernández, H.; Ilyina, A. Immobilization of Aspergillus niger lipase on chitosan-coated magnetic nanoparticles using two covalent-binding methods. Bioprocess Biosyst. Eng., 2015, 38(8), 1437-1445. [http://dx.doi.org/10.1007/s00449-015-1385-8] [PMID: 25759161]

[55] dos Santos, J.C.; Rueda, N.; Gonçalves, L.R.; Fernandez-Lafuente, R. Tuning the catalytic properties of lipases immobilized on divinylsulfone activated agarose by altering its nanoenvironment. Enzyme Microb. Technol., 2015, 77, 1-7. [http://dx.doi.org/10.1016/j.enzmictec.2015.05.001] [PMID: 26138393]

[56] Palomo, J.M.; Ortiz, C.; Fuentes, M.; Fernandez-Lorente, G.; Guisan, J.M.; Fernandez-Lafuente, R. Use of immobilized lipases for lipase purification via specific lipase-lipase interactions. J. Chromatogr. A, 2004, 1038(1-2), 267-273. [http://dx.doi.org/10.1016/j.chroma.2004.03.058] [PMID: 15233541]

[57] Kordel, M.; Hofmann, B.; Schomburg, D.; Schmid, R.D. Extracellular lipase of Pseudomonas sp. strain ATCC 21808: purification, characterization, crystallization, and preliminary X-ray diffraction data. J. Bacteriol., 1991, 173(15), 4836-4841. [http://dx.doi.org/10.1128/jb.173.15.4836-4841.1991] [PMID: 1856176]

[58] Bradford, M.M. A rapid and sensitive method for the quantitation of microgram quantities of protein utilizing the principle of protein-dye binding. Anal. Biochem., 1976, 72, 248-254. [http://dx.doi.org/10.1016/0003-2697(76)90527-3] [PMID: 942051]

[59] Sadana, A.; Henley, J.P. Single-step unimolecular non-first-order enzyme deactivation kinetics. Biotechnol. Bioeng., 1987, 30(6), 717-723. [http://dx.doi.org/10.1002/bit.260300604] [PMID: 18581490]

[60] Fernandez-Lorente, G.; Palomo, J.M.; Cabrera, Z.; Fernandez-Lafuente, R.; Guisán, J.M. Improved catalytic properties of immobilized lipases by the presence of very low concentrations of detergents in the reaction medium. Biotechnol. Bioeng., 2007, 97(2), 242-250. [http://dx.doi.org/10.1002/bit.21230] [PMID: 17054124]

[61] Gupta, M.N. Thermostabilization of proteins. Biotechnol. Appl. Biochem., 1991, 14, 1-11.

[62] Blanch, H.W.; Clarck, D.S. Biochemical Engineering; Marcel Dekker Inc.: New York, 1997.

[63] Pereira, E.B.; De Castro, H.F.; De Moraes, F.F.; Zanin, G.M. Kinetic studies of lipase from Candida rugosa: a comparative study between free and immobilized enzyme onto porous chitosan beads. Appl. Biochem. Biotechnol., 2001, 91-93, 739-752. [http://dx.doi.org/10.1385/ABAB:91-93:1-9:739] [PMID: 11963902]

[64] Soares, C.M.; Santos, O.A.; Castro, H.F.; Moraes, F.F.; Zanin, G.M. Studies on lipase immobilization in hydrophobic sol-gel matrix. Appl. Biochem. Biotechnol., 2004, 113, 307-319. [http://dx.doi.org/10.1385/ABAB:113:1-3:307] [PMID: 15054215]

[65] Bagi, K.; Simon, M.; Szajá, B. Immobilization and characterization of porcine pancreas lipase. Enzyme Microb. Technol., 1997, 20, 531-535. [http://dx.doi.org/10.1016/S0141-0229(96)00190-1]

[66] Pereira, E.B.; Zanin, G.M.; Castro, H.F. Immobilization and catalytic properties of lipase on chitosan for hydrolysis and esterification reactions. Braz. J. Chem. Eng., 2003, 20, 343-355. [http://dx.doi.org/10.1590/S0104-66322003000400002]

[67] Kennedy, J.F.; White, C.A. Handbook of Enzyme Biotechnology; Wiseman, A., Ed.; Ellis Horwood: London, 1985, pp. $147-207$.

\section{(C) 2017 Perna et al.}

This is an open access article distributed under the terms of the Creative Commons Attribution 4.0 International Public License (CC-BY 4.0), a copy of which is available at: https://creativecommons.org/licenses/by/4.0/legalcode. This license permits unrestricted use, distribution, and reproduction in any medium, provided the original author and source are credited. 